\title{
Building the Bibliothèque Choisie, from Jean Le Clerc to Samuel Formey: Library Manuals, Review Journals and Auction Catalogues in the Long Eighteenth Century
}

\author{
Alicia C. Montoya
}

The increasing availability of books, coupled with the emergence of various kinds of bibliographical guides, gave new urgency to the question of how to put together a personal library in the seventeenth and eighteenth centuries. New bibliographical publications included inventories of both institutional and private libraries, that received a significant impetus with the introduction of printed auction catalogues around 16oo; library manuals such as Gabriel Naudé's widely-cited Advis pour dresser une bibliothèque, published in 1627; and the new genre of review journals inaugurated by the founding in Paris, in January 1665, of Denis de Sallo's Journal des Savants. As Claude Jolly notes, by the mid-seventeenth century, a new set of cultural practices had emerged around collection building. 'Little by little, the correspondences of the citizens of the Republic of Letters, the development of bibliography, the reviews published in scholarly periodicals, and the proliferation of auction catalogues would come to constitute the basis of rationalized collecting habits.' ${ }^{1}$ In the following pages, I argue that subsequent to these changes, in the eighteenth century a triangular relationship developed between three types of publication - library auction catalogues, review journals and library manuals - that invites us to study them comparatively, as part of a larger commercial and cultural system. To make this argument, I examine the notion of the Bibliothèque Choisie, as this took shape initially in review journals such as Jean Le Clerc's Bibliothèque choisie (1703-1713) and thereafter in library manuals like Samuel Formey's Conseils pour former une bibliothèque peu nombreuse

1 Claude Jolly, 'Annexe: Naissance de la "science" des bibliothèques', in Claude Jolly (ed.), Histoire des bibliothèques françaises, vol. 2: Les bibliothèques sous l'Ancien Régime 1530-1789 (Paris: Editions du Cercle de la Librairie, 2008), p. 49o. My translations throughout. This project has received funding from the European Research Council (ERC) under the European Union's Horizon 2020 research and innovation programme under grant agreement No. 682022 . 
mais choisie, that went through six editions between 1746 and 1764 . I focus particularly on how the concept of the bibliothèque choisie might be reflected in the real library holdings of individuals whose libraries were sold at auction in the eighteenth century, and conclude with some remarks on how aggregating data from different sources might help answer questions about 'the meaning of the library', or what these different book lists represent, if not (wholly or exclusively) real book collections, and what other commercial and discursive purposes they may have fulfilled for booksellers, library owners, and the interpretive communities to which they belonged ${ }^{2}$

\section{Library Manuals, Sales Catalogues, Review Journals - and Relations between Them}

Among the new bibliographic aids to collection forming that gained prominence in the seventeenth and eighteenth centuries, one of the most frequently referenced were library inventories or catalogues. In his Advis pour dresser une bibliothèque, cardinal Mazarin's future librarian Gabriel Naudé recommended that collectors pay special attention to the printed catalogues of existing libraries as models in selecting titles for their own collection. The use in this period of catalogues of institutional libraries and booksellers' stock catalogues as bibliographic reference tools or book 'shopping lists' has been widely documented. ${ }^{3}$ In the late seventeenth and eighteenth century, as the business of auctioning private libraries expanded, printed auction catalogues of privately-owned libraries were in turn incorporated into these practices. In the Dutch Republic, this practice was cemented by the voluminous printed catalogue drawn up in 1683 for the sale of Nicolaas Heinsius's 13,00o volume library, that quickly became a bibliographic fixture in scholars' libraries. By mid-century, in France, the Encyclopédie article 'Catalogue' advised readers building their own collections to follow the model provided by the auction catalogues of the libraries of Charles Bulteau, sold in 1712; Charles-Jérôme de Cisternay Du Fay, sold in 1725; count Charles-Henry d'Hoym, sold in 1738; Toussaint Bellanger, sold in 1740; and abbé d'Orléans de Rothelin, sold in $1746 .{ }^{4}$ At century's end, summing

2 Alice Crawford (ed.), The meaning of the library: A cultural history (Princeton: Princeton University Press, 2015).

3 For some examples, see Gerda C. Huisman, 'Inservio studiis Antonii a Dorth Vesaliensis: The many uses of a seventeenth-century book sales catalogue', Qucerendo, 41 (2011), p. 278.

4 Bulteau's sales catalogue, Bibliotheca Bultelliana, long remained a model of bibliographic classification. Françoise Bléchet, 'Glanes bibliographiques sur quelques grandes ventes publiques: La politique d'acquisition de la Bibliothèque du Roi', in Annie Charon and Elisabeth 
up what appeared to have become a general consensus, a series of articles in The Gentleman's Magazine in 1788 and 1794 recommended the 'circulation of learning by catalogues. ${ }^{5}$ The fact that so many auction catalogues of private libraries were reported in other private libraries testifies to the new uses to which these catalogues were frequently put after the original auction had taken place. ${ }^{6}$

Auction catalogues were not the only bibliographic reference tool used by collectors putting together their own library. From the late seventeenth century onward, two other new sources of information on recent publications became available to readers dealing with their age's information overload: review journals and library manuals, whose stated purpose was to help readers select and organize their own library. Naudé's Advis pour dresser une bibliothèque set the tone. His book was reissued in 1644, translated into English in 1661, and twice into Latin, in 1658 and in $1703 .^{7}$ Naudé's book inspired other publications, including also more general treatises on libraries such as, in the Dutch Republic, the Zutphen pastor Johannes Lomeier's De bibliothecis liber singularis, first published in $1669 .{ }^{8}$ During the eighteenth century, subsequently, the genre grew quantitatively and significantly diversified its content and target audiences. Whereas Naudé's Advis had sought to help prominent noblemen or magistrates put together a 'fine and sumptuous library' comprising thousands of volumes and encompassing 'all the principal authors who have written on the great diversity of particular subjects, and principally on all the arts

Parinet (eds.), Les ventes de livres et leurs catalogues, $X V I I^{e}-X X^{e}$ siècle (Paris: Ecole des Chartes, 200o), p. 83. Michel-Antoine David, 'Catalogue', in Encyclopédie, ou dictionnaire raisonné des sciences, des arts et des métiers, etc., ed. Denis Diderot and Jean le Rond d'Alembert, vol. 2 (1752), p. 761 (University of Chicago: Artfl Encyclopédie Project, Autumn 2017 Edition), ed. Robert Morrissey and Glenn Roe, http://encyclopedie.uchicago.edu/ [accessed 5 September 2018].

5 Cited in James Raven, 'From promotion to proscription: Arrangements for reading and eighteenth-century libraries', in James Raven, Helen Small and Naomi Tadmor (ed.), The practice and representation of reading in England (Cambridge: Cambridge University Press, 1996), p. 192.

6 See chapter fourteen, above. There are many examples of this phenomenon. The library of the Reverend Michael Lort, sold in 1791, contains 55 catalogues, of which 46 are of private libraries. In Lille, the unknown collector of eighteenth-century library catalogues now in the municipal library apparently used them as checklists, marking titles he already possessed. Examples cited in Helwi Blom, Rindert Jagersma and Juliette Reboul, 'Printed private library catalogues as a source for the history of reading', in Mary Hammond (ed.), The Edinburgh history of reading. Early Readers. (Edinburgh: Edinburgh University Press, 2020).

7 Horst Kunze, 'Epilogue', in Gabriel Naudé, Advis pour dresser une bibliothèque (Paris: François Targa, 1627, reprint Leipzig: veв Edition, 1963), p. 141.

8 Johannes Lomeier, De bibliothecis liber singularis (Zutphen: Henricus Beerren, 1669). 
and sciences', the library advice books published in the eighteenth century targeted intellectually more modest audiences, and had more circumscribed aspirations. ${ }^{9}$ The proliferation of the genre during this period was part of a broader process of cultural democratisation, reflecting widely-shared Enlightenment ideals of self-improvement, intellectual sociability and the intersection of public utility and private leisure. Typically, these new library advice books took the form of a text ranging from a dozen pages to several volumes, that discussed the books a well-born individual should read beyond any direct professional needs. The text was often divided into chapters, each addressing a particular subject category, with the subject categorisation repeated in the list of books sometimes appended to the work's main, discursive section. As in other bibliographic works, these categorisations also transmitted specific hierarchies of knowledge and cultural values. The discussion of the books recommended could be very brief, sometimes no more than an approving reference to a specific title, or more thorough, running to many pages of critical commentary.

The third new bibliographic reference genre that emerged during the eighteenth century was the review journal. As Ian MacLean argues in his contribution to this volume, the demise of the Frankfurt book fair catalogues after 1700 was predicated in part on the rise of a competing genre, that of scholarly journals published in France, England, and the Dutch Republic. Scholarly journals offered a less conservative view of the literary field than did the trade catalogues; they also provided more depth and substantive criticism of the works being offered for sale, thereby presenting readers with additional help in finding their way among the mass of new publications. This library-building function was widely acknowledged by contemporaries, right from the start. Upon perusing the first issues of the recently founded Journal des Savants, for example, Jacob Bayle wrote enthusiastically to his brother Pierre, the future editor of the Nouvelles de la République des Lettres, that 'nothing considerable concerning the world of letters happens in Europe that this journal does not report. This journal is therefore very useful to anyone wanting to put together a library, since he can make an excellent choice of books following the indications it provides. ${ }^{\prime 0}$ In the eighteenth century, thanks to the work of the Swiss-born Protestant journalist Jean Le Clerc and others, several new review journals were founded that openly acknowledged their library-building, guidebook

$9 \quad$ Naudé, Advis, p. 11, 31.

10 Correspondance de Pierre Bayle, ed. Elisabeth Labrousse, Edward James, Antony McKenna, Maria-Cristina Pitassi and Ruth Whelan (Oxford: Voltaire Foundation, 1999), vol. 1, pp. 19-20. 
function in their titles, starting with Le Clerc's own Bibliothèque universelle et historique (1686-1693), and its successors, the Bibliothèque choisie pour servir de suite à la Bibliothèque universelle (1703-1708) and Bibliothèque ancienne et moderne (1714-1727). ${ }^{11}$

That there are close relations between eighteenth-century library manuals, review journals, and book sales catalogues can be inferred, first of all, from their positioning in the literary-commercial field. The publishers of book trade catalogues, editors of review journals, and authors of library advice books were not infrequently one and the same person. In many cases, they belonged to cognate professional networks, with multiple links bringing them together, often but not always in configurations that could be loosely identified with the international Republic of Letters. ${ }^{12}$ But there were also formal similarities between these publications. Most obviously, library manuals, review journals and library auction catalogues shared similar titles, that foregrounded terms such as bibliotheca, bibliothèque, boekzaal or other expressions referring to the physical library. Sales catalogues, like some sections of library manuals and review journals, further adopted the basic form of the book list to convey their information. Library manuals and review journals were similar in content because of their stated aim to help readers make choices among the enormous mass of reading material now available to them. Just as Naudé had stressed that 'we cannot by our sole industry know and understand the qualities of such a large number of books as one must own', the Histoire des ouvrages des savants referred to the 'deluge and inundation of books' that present-day readers faced. ${ }^{13}$ In the foreword to his Bibliothèque choisie, Jean Le Clerc noted that it would be impossible for a single reader to read all the works making up 'an ocean of readings, that one would be unable to exhaust', and that it was therefore up to review journals and their judicious editors to provide the necessary advice. ${ }^{14}$ Both genres additionally targeted new reading audiences, often with an explicitly stated popularising mission. In the foreword to his Bibliothèque choisie Le Clerc underscored the fact that the reading public now included new

11 Other titles included Richard Simon and Nicolas Barat's Bibliothèque critique (1708-1710), Michel de La Roche's Bibliothèque anglaise (1717-1728), and Jacques Lenfant's Bibliothèque germanique (1720-1740). For a full list, see Jean Sgard (ed.), Dictionnaire des journaux 1600-1789 (2 vols., Oxford: Voltaire Foundation - Paris: Universitas, 1991).

12 Hans Bots dates the decline of the Republic of Letters to the second half of the eighteenth century, when the international ideal broke down into nationally-oriented components. Hans Bots, De republiek der letteren. De Europese intellectuele wereld 1500-1760 (Nijmegen: Vantilt, 2018).

13 Naudé, Advis, p. 26. Histoire des ouvrages des savants, July 1688, p. 39.

14 Jean Le Clerc, 'Avertissement', in Bibliothèque choisie pour servir de suite à la Bibliothèque universelle (Amsterdam: Henri Schelte, 1712 [1703]), vol. 1, unpaginated. 
categories of readers who might not have had the education necessary to read learned works for themselves, but were nonetheless 'persons of good sense ... that do no not own large libraries and are in need of some guidance..$^{15}$

Similarities between library manuals and book trade catalogues were most pronounced, perhaps, in the case of private library auction catalogues. Contrary to booksellers' stock catalogues, and like library manuals, private library auction catalogues included older books as well as recent publications. Like library manuals, auction catalogues also foregrounded the figure of the collector. The content of a privately-owned library, after all, was dictated not primarily by commercial motives, such as the existence of books in stock that a bookseller wanted to dispose of, but by the persona of the collectors themselves. As such, private library catalogues supposedly reflected the professional activity, personal taste and discernment of their (deceased) owners - even if in practice, commercial motives were never entirely absent. ${ }^{16}$ Both auction catalogues and library manuals therefore functioned as elements within broader processes of self-fashioning, expressing idealised images of a model reader and an intellectual culture associated with a specific societal group. Private taste, in short, was fortuitously married here to widely-shared values in the public sphere. As Naudé had instructed his readers, 'there is no more honest and surer way to acquire a great reputation among the populace, than to erect a fine and magnificent library, in order to dedicate it afterwards to the use of the public'17

\section{The Bibliothèque Choisie, an Eighteenth-Century Concept}

In the course of the eighteenth century, conceptualisations of the ideal library began to change, breaking with the tradition exemplified by Naudés earlier Advis, with its ideal of a library put together by a prominent collector for the public good. Whereas Naudés model was indebted to the scholarly ideal of the bibliothèque universelle, that sought to capture the sum of human knowledge in its encyclopedic, biblioholic approach to collection forming, by the mid-eighteenth century, with the exponential increase of new publications flooding the market, the ideal of the universal library fell into neglect, except in the institutional context of a few, progressive university libraries. Instead, as

15 Le Clerc, 'Avertissement', unpaginated.

16 For an overview of the issues involved in using private library auction catalogues as a description of their owners' collections, see Blom, Jagersma and Reboul, 'Printed private library catalogues as a source'.

17 Naudé, Advis, p. 18. 
Jonathan Israel has argued, the ideal of universality was preserved in the rise of a new genre of encyclopaedias, dictionnaires and other compendia, often reflecting modern Enlightenment ideas: not the size of the library, but its contents henceforth defined its character. ${ }^{18}$ Reflecting this changing reality, review journals and library manuals began to put forth a novel concept, that of the bibliothèque choisie, or an ideal type of smaller, private library that reflected its owner's personal taste. The bibliothèque choisie drew on the ideals exemplified by the honnête homme, whose aristocratic, amateur approach to literature was far removed from the professional, practical concerns of scholars. ${ }^{19}$ The new, smaller type of library was further associated with courtly or aristocratic mondain culture, and presented itself as similar in some ways to the cabinet of curiosities, bringing together objects that could function as sociable conversation pieces. Importantly, while the scholar's encyclopedic library completely excluded modern literature or belles-lettres, this last category of works occupied a prominent place in the bibliothèque choisie. This meant that, as I have argued elsewhere, there was also a distinct gender dimension to this concept, since the lack of professional affiliation of women, in particular, made of them in many ways the ideal readers of this new kind of library. ${ }^{20}$ The increasing participation of women in the literary field, especially in France, thus provided an impulse to re-imagine the library as a site of non-professional, cultured sociability, associating reading not with hard intellectual labour - as in the model of the scholar exemplified by St Jerome bent over his books - but with disinterested reading and enjoyment. Notions of the bibliothèque choisie, hence, reflected what has been described as the 'major cultural evolution of the modern period': the idea of reading for private pleasure. ${ }^{21}$

The term bibliothèque choisie, after a first few occurrences in the seventeenth century, gained traction in the initial decades of the eighteenth century. Significantly, the term bibliothèque choisie first gained prominence thanks to the work not of librarians but of journalists, notably Jean Le Clerc, who titled the second review journal he published in Amsterdam, starting in 1703, Bibliothèque choisie. In the programmatic 'Avertissment' preceding the first

18 Jonathan I. Israel, 'Libraries and Enlightenment', in his Radical Enlightenment: Philosophy and the making of modernity 1650-1750 (Oxford: Oxford University Press, 2001), pp. 134-137.

19 On the relation between sociable ideals of honnêteté and the bibliothèque choisie, see Jean-Marc Chatelain, La bibliothèque de l'honnête homme. Livres, lecture et collections en France à l'âge classique (Paris: Bibliothèque nationale de France, 2003).

20 Alicia C. Montoya, 'A woman reader at the turn of the century: Maria Leti Le Clerc's 1735 library auction catalogue', in Tom Carr and Russell Ganim (ed.), Origines: Actes du $39 e$ congrès annuel de la North American Society for Seventeenth-Century French Literature (Tübingen: Gunter Narr, 2009), pp. 129-140.

21 Alexandre Wenger, La fibre littéraire. Le discours médical sur la lecture au XVIII e siècle (Geneva: Droz, 2007), pp. 144-145. 
issue, Le Clerc set out his definition of the bibliothèque choisie, writing that 'I have no design other than to speak haphazardly of ancient and modern books, as they come into my hands or as I read them, as I am wont to do, without observing in this any order, and without regard to the time in which they were first published ... it will not be necessary for me to read, despite myself, those books I deem not worth my while.'22 The two defining features of the bibliothèque choisie were therefore, first, its lack of a systematic organising principle, and secondly, the fact that it was a collection comprising the best that had been written over the centuries, regardless of the subject, chosen on the basis of personal taste and excluding 'those books I deem not worth my while'. This model of the library was clearly different from the encyclopedic, scholarly library that Le Clerc had described in his previous periodical, the Bibliothèque universelle et historique (1686-1693), the forerunner of the Bibliothèque choisie. Although Le Clerc did not explicitly reference belles-lettres as a distinct subject category in this new kind of ideal library, the changing content of his review journal reflected his increasing valorisation of this class of books. A statistical overview of the content of the books reviewed in the two periodicals (Table 15.1), based on the division into five major categories adopted by Parisian booksellers in the eighteenth century, and subsequently by modern historians, demonstrates the growing importance Le Clerc accorded to belles-lettres, that increases from $15 \%$ to $25 \%$ of the journal content, and the decreasing importance of the categories 'Religion' and the category 'Arts and sciences', that covered both philosophy and practical disciplines such as medicine, mathematics and the military arts. ${ }^{23}$

TABLE 15.1 Categorisation of books reviewed in Le Clerc's periodicals

\begin{tabular}{lcc}
\hline & $\begin{array}{l}\text { Bibliothèque universelle, } \\
\mathbf{1 6 8 6 - 1 6 9 3}\end{array}$ & $\begin{array}{l}\text { Bibliothèque choisie, } \\
\mathbf{1 7 0 3 - 1 7 1 3}\end{array}$ \\
\hline Religion & $31 \%$ & $27 \%$ \\
Law & $5 \%$ & $5 \%$ \\
History & $23 \%$ & $22 \%$ \\
Arts and sciences & $21 \%$ & $13 \%$ \\
Belles-lettres & $15 \%$ & $25 \%$ \\
Other & $5 \%$ & $8 \%$ \\
\hline
\end{tabular}

22 Le Clerc, 'Avertissement', unpaginated.

23 For a full statistical overview, see Guus N.M. Wijngaards, De Bibliothèque choisie van Jean Le Clerc: een Amsterdams geleerdentijdschrift uit de jaren 1703 tot 1713 (PhD dissertation, Radboud University, 1986). 
How influential was Le Clerc's conceptualisation of the bibliothèque choisie in practice? One source that allows historians to verify the impact of changing views of the ideal library on collecting habits are the printed catalogues of private libraries sold at auction. Interestingly, one of the eighteenth-century collectors whose library was documented in an auction catalogue was Le Clerc himself. As his health was failing and four months before his death, Le Clerc asked the Amsterdam booksellers Jacobus Wetstein and William Smith to draw up a catalogue of his personal library, together with that of his wife Maria Leti, who had passed away ten months earlier. The two libraries were sold at auction starting on September 6, 1735. Given Le Clerc's position as a prominent member of the Republic of Letters, the sale drew considerable attention. This is testified both by the multiple copies of the catalogue that have survive and by the many advertisements for the sale that appeared in the press. ${ }^{24}$ The catalogue of Le Clerc's library numbered 2,756 lots, excluding manuscripts, that were listed separately. An overwhelming majority of the lots $-2,220$, or $81 \%$ - listed books in Latin. In this sense, Le Clerc's was not a particularly modern library. By comparison, the library of another contemporary early Enlightenment figure, with whom Le Clerc himself entertained close relations, John Locke, listed only a third of the books in Latin, another third in English, and 18\% in French (versus only $9 \%$ in Le Clerc's library). ${ }^{25}$

Le Clerc's catalogue was divided into fourteen subject categories, starting as in the Parisian booksellers' system - with the foremost of them, theology and its various subdivisions ('Biblia, Bibliorum Concordantiæ \& Lexica', etc.), representing $38 \%$ of the total (versus less than a quarter of the total in Locke's library) and working down from there, in the conventional order, through jurisprudence to the other, lesser headings. Philosophy books were lumped together, as was usual, with the other 'Arts and sciences' in the blanket category 'Philosophici, Medici, Mathematici Veteres \& Recentiores, \& Historiæ

24 Brill's Book Sales Catalogues Online database (henceforth BSCO) lists 21 existing copies of the catalogue, an exceptional number since most catalogues survived only in a single copy. Bert van Selm, J.A. Gruys, and H.W. de Kooker (ed.), continued by Karel Bostoen, Otto Lankhorst, Alicia C. Montoya and Marieke van Delft (eds.), Book Sales Catalogues Online - Book Auctioning in the Dutch Republic, ca. 1500-ca. 1800, http://primarysources. brillonline.com/browse/book-sales-catalogues-online [accessed 6 September 2018]. I have identified twelve announcements in all, that appeared in the Amsterdamse Courant and the Leydse Courant between 7 July and 12 September. The advertisements referenced the manuscripts and magnificent, six-volume sea atlas that would be sold, but made no mention of the library of Le Clerc's wife, that was sold alongside his.

25 Locke's library was larger than Le Clerc's, numbering 3,641 items. John Harrison and Peter Laslett, The library of John Locke (Oxford: Oxford Bibliographical Society, 1965), p. 19. 
Naturalis Scriptores'. Just as the collection's Latin-language focus revealed its debt to traditional, humanistic models of scholarship, so too did its organisation into subject categories - due most likely to the Amsterdam booksellers Wetstein and Smith - reproduce without questioning the traditional hierarchies of knowledge.

In contradiction to his advocacy of the bibliothèque choisie, therefore, the size and comprehensiveness of Le Clerc's own library seemed to betray a lingering allegiance to the older ideal of the encyclopedic, universal library. While some scholars have identified the universal with Enlightenment ideas, qualifications are called for in the case of Le Clerc's library. ${ }^{26}$ The proportion of religious books, at $38 \%$, remained relatively high, but is in keeping with his role as a leading advocate of a moderate Enlightenment, defined by a rationalist Christian theology. ${ }^{27}$ This ambivalent position also explains the relatively modest place occupied by 'Libri philosophici' in his library auction catalogue. Yet at the same time, despite its conventional categorisation schema, a comparison of the subject distribution of the books reviewed in the Bibliothèque choisie and the books listed in his library auction catalogue (Table 15.2) reveals that Le Clerc's was also, in other respects, a markedly modern collection. This was especially evident in the relative importance of the category 'Belles-lettres'. Covering $23 \%$ of the book lots recorded in the auction catalogue, this proportion was closer to the proportions obtained in his Bibliothèque choisie $(25 \%)$ than those in his earlier periodical, the Bibliothèque universelle (15\%).

TABLE 15.2 Categorisation of book lots in Le Clerc's library auction catalogue

\begin{tabular}{lccc}
\hline & $\begin{array}{l}\text { Bibl. universelle, } \\
\mathbf{1 6 8 6 - 1 6 9 3}\end{array}$ & $\begin{array}{l}\text { Bibl. choisie, } \\
\mathbf{1 7 0 3 - 1 7 1 3}\end{array}$ & $\mathbf{1 7 3 5}$ catalogue \\
\hline Religion & $31 \%$ & $27 \%$ & $38 \%$ \\
Law & $5 \%$ & $5 \%$ & $4 \%$ \\
History & $23 \%$ & $22 \%$ & $12 \%$ \\
Arts and sciences & $21 \%$ & $13 \%$ & $16 \%$ \\
Belles-lettres & $15 \%$ & $25 \%$ & $23 \%$ \\
Other & $5 \%$ & $8 \%$ & $7 \%$ \\
\hline
\end{tabular}

26 Israel, Radical Enlightenment, pp. 119-127.

27 On Le Clerc's religious views, see Israel, Radical Enlightenment, pp. 464-471. 
Contrary to a common narrative in French book history, the category 'Religion' did not decrease but rather increased between the publication dates of Le Clerc's two journals, 1686-1713, and the date of the auctioning of his books, 1735 . This most likely reflects the fact that libraries typically contained many older, 'legacy' works, that did not necessarily reflect their owner's current intellectual preoccupations. Le Clerc's library is further notable for the presence in it of large numbers of older books, including incunabula.

More interesting still, however, from a comparative perspective, is the catalogue appended to Le Clerc's: that of the personal library of his wife and longtime intellectual helpmate Maria Leti. The daughter of the Italian adventurer-historian Gregorio Leti, Maria Leti Le Clerc was a learned woman in her own right. As I have discussed elsewhere, Maria Leti's library auction catalogue is a unique example of a library auction catalogue whose contents can be attributed solely to a female owner - her father Gregorio Leti's books had been the subject of an earlier auction, in 1701 - and that, in addition, reflects its owner's singularly modern literary taste. ${ }^{28}$ The majority of the books in Maria Leti's library, two thirds of the total library holdings, were acquired after 1690. The language distribution, too, heavily favoured recent, mondain publications, with fully $6 \circ 0$, or $89 \%$ of the books listed, in French, and only 6 , or less than $1 \%$, in the language most often reported in her husband's catalogue, Latin, a language that Maria Leti was most likely unable to read herself. Maria Leti's library, even more than her husband's, might, then, be considered a prime exemplar of that new kind of collection, the non-professional bibliothèque choisie, that was emerging in the eighteenth century.

As Table 15.3 shows, Maria Leti's personal library came close in many respects to the ideals put forth in her husband's Bibliothèque choisie. The percentage of religious works in her library, $27 \%$, more closely approximated the proportions reviewed in this periodical: $27 \%$, as opposed to $38 \%$ of religious works in Le Clerc's own library. ${ }^{29}$ The proportion of books in the categories 'History' and 'Belles-lettres' was also comparable to the proportion of books in those categories reviewed in the Bibliothèque choisie. The only notable discrepancy was in the category 'Arts and sciences', which primarily referred to works used in the practice of professions closed to women, and therefore made a poor showing in Maria Leti's library auction catalogue.

28 Montoya, 'A woman reader'.

29 If uncategorised works are excluded from the calculations, then the percentages become $41 \%$ (Le Clerc), $32 \%$ (Leti) and 29\% (Bibliothèque choisie). 
TABLE 15.3 Categorisation of book lots in the library catalogues of Jean Le Clerc and Maria Leti

\begin{tabular}{lccc} 
Subject category & Jean Le Clerc & Maria Leti & Bibl. choisie \\
\hline Religion & $1.049(38 \%)$ & $183(27 \%)$ & $27 \%$ \\
Law & $124(4 \%)$ & $16(2 \%)$ & $5 \%$ \\
History & $323(12 \%)$ & $198(29 \%)$ & $22 \%$ \\
Arts and sciences & $451(16 \%)$ & $48(7 \%)$ & $13 \%$ \\
Belles-lettres & $621(23 \%)$ & $188(28 \%)$ & $25 \%$ \\
Uncategorised & $188(7 \%)$ & $44(7 \%)$ & 8 \\
\hline
\end{tabular}

\section{Library Manuals and Their Audiences}

From its first iterations in review journals, and possibly the libraries of exceptional individuals such as Maria Leti Le Clerc, the concept of the bibliothèque choisie migrated to the new genre of library manuals. Library manuals, like bibliographic reference works more generally, had a long pedigree, going back at least to Antiquity but re-emerging in new guises during the early modern period. ${ }^{30}$ In library manuals, the first occurrences of the term bibliothèque choisie appear to date to the first decade of the eighteenth century. Surely not coincidentally, borrowing from the success of Le Clerc's periodicals, the first of these manuals were published in the Dutch Republic, by Dutch booksellers. In 1714, a posthumously published library manual by the Paris-based author Nicolas Barat was brought out by the Amsterdam bookseller David Mortier under the title Nouvelle bibliothèque choisie, où l'on fait connoître les bons livres en divers genres de littérature. As David McKitterick comments on this publication, 'no harm was to be done in publishing work by a respected author that lauded books that were in a bookseller's stock, and where an international trade could be expected. ${ }^{31}$ In 1731, in a work that appeared in The Hague, Introduction générale à l'étude des sciences, the prolific Antoine-Augustin Bruzen de La Martinière described his volume's aim as being the constitution of a 'cabinet

30 Ann M. Blair, Too much to know: Managing scholarly information before the modern age (New Haven: Yale University Press, 2010), pp. 56-57, 119-120.

31 David McKitterick, The Invention of rare books: Private interest and public memory, 160o1840 (Cambridge: Cambridge University Press, 2018), p. 56. 
of choice books' (un cabinet de livres choisis). ${ }^{32}$ Around the same time, the Belgian jurist-author Charles-François Custis produced a manuscript library manual that used a similar term in the title, Bibliothèque choisie d'un gentilhomme, ou instruction d'un père à son fils pour lui ouvrir le chemin aux belles lettres, aux arts, et aux sciences, composed sometime between 1736 and $1740 .{ }^{33}$ It was therefore hardly surprising that at mid-century, the most successful library manual author of all, Samuel Formey, foregrounded this concept in the title of his Conseils pour former une bibliothèque peu nombreuse mais choisie, first published in Berlin in 1746 by Ambrosius Haude and Johann Carl Spener.

Although in the eighteenth century, library manuals were not limited to a single geographic region, it was in France, with its strong bookselling infrastructure and vernacular market, as well as the prominent role of women in the literary field, that the genre developed most fully. While English readers could turn to translations of Naudés text or to later titles such as John Boswell's Method of study, or a useful library (1738) or John Whiston's Directions for a proper choice of authors to form a library (1766), and German collectors could consult Johann Christoph Stockhausen's Critischer Entwurf einder auserlesenen Bibliothek (1752), the number of library manuals available to French-language readers in this period far surpassed what was produced elsewhere, and ran to over a dozen distinct titles. ${ }^{34}$ Some of these texts were short pieces published within larger collections, while others were books in their own right. They range in size from François de La Mothe Le Vayer's ten-page essay 'Lettre sur les moyens de dresser une bibliothèque d'une centaine de livres seulement', originally published in 1654 , to Antoine-Alexandre Barbier and bookseller Nicolas Le Moyne Des Essarts' five-volume, comprehensive Nouvelle Bibliothèque d'un homme de goût ... contenant des jugements tirés des journaux

32 [Antoine-Augustin Bruzen de La Martinière], Introduction générale à l'étude des sciences et des belles-lettres en faveur des personnes qui ne savent que le français (The Hague: Isaac Beauregard, 1731), p. v.

33 Tom Verschaffel, 'Un guide de lecture historique au dix-huitième siècle: Charles-François Custis (1704-1752) et sa bibliothèque idéale', Lias: Journal of Early Modern Intellectual Culture and its Sources, 17 (1990), pp. 109-119.

34 John Boswell, A method of study: or, an useful library. In two parts ... (London: printed for the author, 1738). N.N. [John Whiston?], Directions for a proper choice of authors to form a library, which may both improve and entertain the mind (London: J. Whiston, J. Dodsley, J. Robson, 1766). [Johann Christoph Stockhausen], Critischer Entwurf einer auserlesenen Bibliothek für den Liebhaber der Philosophie und schönen Wissenschaften. In einigen Sendschreiben an einen Freund (Berlin: Haude \& Spener, 1752). Although Leibniz had earlier drawn up a bibliography of works that should be included in an ideal library, the size of this collection - 2,500 works - betrays its debt to the ideal of the universal library rather than the new bibliothèque choisie. Israel, Radical Enlightenment, p. 126. 
les plus connus et des critiques les plus estimés, sur les meilleurs ouvrages qui ont paru dans tous les genres, that appeared in $1808 . .^{35}$ Barbier and Des Essarts' compendium was in fact the last incarnation of a particularly successful library manual, whose original, bearing the title Bibliothèque d'un homme de goût, had been published by the Provençal librarian abbé Louis-Mayeul Chaudon in $1772 .{ }^{36}$ Chaudon's volume was swiftly appropriated by other authors, who published revised versions of his original text, under the same title. The text was thoroughly revamped by the prolific abbé Joseph de La Porte in 1777, and by Des Essarts in $1798-1799 .{ }^{37}$ Formey's Conseils pour former une bibliothèque, similarly, went through multiple editions, as I discuss below.

The authors of French-language library manuals were typically men and women of letters of middle-class or aristocratic extraction. Several of them were professional educators: La Mothe Le Vayer had been tutor to Louis XIV, and Mme de Genlis, the author of a 'Cours de lecture' included as an appendix to her best-selling pedagogical novel Adèle et Théodore ou lettres sur l'éducation (1782), was gouverneur to the Orléans children at the end of the century. Only one of them, Chaudon, described himself as a librarian by training. ${ }^{38}$ Just as authors of these works were not scholars, so too was their intended audience composed of non-professional, amateur readers. In his foundational Introduction générale à l'étude des sciences, La Martinière addressed a mixed public made up of young people, officers, noblemen, and 'those whose lessons were lacking' and who therefore could only read works in French. From La Martinière onwards, library manuals targeted well-born, non-scholarly audiences: Chaudon's 1772 volume had as its ideal reader a 'man of taste' who only read French; Contant d'Orville's Manuel des châteaux ou lettres contenant des

35 Antoine-Alexandre Barbier and Nicolas Le Moyne des Essarts, Nouvelle Bibliothèque d'un homme de goût, entièrement refondue, corrigée et augmentée. Contenant des jugements tirés des Journaux les plus connus et des Critiques les plus estimés, sur les meilleurs ouvrages qui ont paru dans tous les genres, tant en France que chez l'Etranger jusqu'à ce jour (5 vols., Paris: Duminil-Lesueur, 1808).

36 [abbé Louis-Mayeul Chaudon], Bibliothèque d'un homme de goût ou Avis sur les meilleurs Livres écrits en notre Langue sur tous les genres de Science \& de Littérature par L.M.D.V. Bibliothécaire de Mgr. le duc de ** (2 vols., Avignon:Joseph Blery, Antoine Aubane, $1772)$.

37 [Abbé Joseph de La Porte], Bibliothèque d'un homme de goût ou Avis sur les meilleurs Livres écrits en notre Langue sur tous les genres de Science \& de Littérature (4 vols., Paris: rue Saint Jacques, au grand Corneille, 1777). [Nicolas Le Moyne des Essarts], Bibliothèque d'un homme de goût ou Tableau de la littérature ancienne et moderne (Paris: Des Essarts, 1798-1799).

38 Stéphanie Félicité Ducrest, comtesse de Genlis, 'Cours de lecture suivi par Adèle depuis lâge de six ans jusqu'à vingt-deux', in Adèle et Théodore, ou Lettres sur l'éducation (Paris: M. Lambert, F.J. Baudouin, 1782), vol. 3, pp. 519-534. 
conseils pour former une bibliothèque romanesque (1779) addressed aristocratic women; while Genlis composed her 'Cours de lecture' as part of her educational programme for girls and young women. ${ }^{39}$ The social position of these intended audiences, in the upper echelons of society despite their neglected education, was not dissimilar to the sub-elite status of real owners of libraries sold at auction during this period - a further commonality suggesting the value of studying private library auction catalogues and library manuals in a comparative perspective. ${ }^{40}$

One of the most explicit statements about the non-professional character of these intended audiences was made by Samuel Formey in the preface to his Conseils. Identifying different categories of potential readers, he emphasised that 'not all people are capable of reading; not all people have the time and the means to attend to this occupation,' and concluded that 'reading is therefore principally the occupation of two classes of people. First, that of professional scholars, or rather it is their job. Secondly, reading generally befits all people of either sex, who having some education, an honest living and leisure time, desire to make use of all these advantages, and add new pleasures to their lives. ${ }^{41}$ While reading audiences had almost exclusively been gendered male in sixteenth- and seventeenth-century library manuals, by the mid-eighteenth century the implicit or explicit inclusion of women among the intended public was widely accepted. This re-gendering of the library was further strengthened, in Formey's text as elsewhere, by the coupling of descriptions of the library with novel notions of pleasure (agrément, in Formey's preface). In this sense, the bibliothèque choisie had obvious affinities with another kind of collection that emerged in the eighteenth century, the so-called bibliothèque de campagne or seasonal, 'travelling' libraries of light, summer reading that explicitly targeted an audience of women readers. ${ }^{42}$ In keeping with the

39 André-Guillaume Contant d'Orville, Manuel des châteaux ou lettres contenant des conseils pour former une Bibliothèque Romanesque (Paris: Moutard, 1779).

40 On the social provenance of owners of libraries sold at auction in the Dutch Republic and Paris, see Michel Marion, Collections et collectionneurs de livres au XVIII ${ }^{e}$ siècle (Paris, Champion: 1999); Alicia C. Montoya, 'French and English women writers in Dutch library auction catalogues, 1700-180o: Some methodological considerations and preliminary results', in Suzan van Dijk, Petra Broomans, Janet van der Meulen and Pim van Oostrum (eds.), "I have heard about you": Foreign women's writing crossing the Dutch bor$\operatorname{der}$ (Hilversum: Verloren, 2004), pp. 182-216.

41 Samuel Formey, Conseils pour former une bibliothèque peu nombreuse mais choisie (Berlin: Ambr. Haude \& J.C. Spener, 1746).

42 María Luisa López-Vidriero, The polished cornerstone of the temple: Queenly libraries of the Enlightenment (London: The British Library, 2005), pp. 11-19. 
bibliothèque choisie's character, the books recommended by library manuals were in the vernacular, and could include translations of the Latin and Greek classics. In contrast to Naudé's Advis, with its lengthy, untranslated Latin citations, and its recommendation that readers consult books in their original language - including Latin, Greek and Hebrew - eighteenth-century authors of library manuals either reduced the length and number of their Latin citations (Formey) or omitted them altogether (La Martinière), reflecting the specific, popularising aims of the bibliothèque choisie.

The amateur nature of the implied reading audience of library manuals was reflected, finally, in the size of the ideal libraries they described. Most often numbering only a few hundred titles, they usually did not exceed 5oo, with a low of around 100 titles in La Mothe Le Vayer's 'Lettre sur les moyens de dresser une bibliothèque' and Genlis's 'Cours de lecture', and highs nearing a thousand in some of the late eighteenth-century manuals. Differences in size can be explained by the different functions of these ideal libraries. La Mothe Le Vayer's bibliothèque choisie, for example, comprised only the most indispensable works, since it was intended more as a reference library than as a complete, personal collection. Assuming that his readers would have access to other libraries as well as their own, he instructed them that:

A man in a great city, full of learned people like this one [Paris], having recourse in some circumstances and studious necessities to the libraries of his friends, and many other libraries to which entrance is relatively free, might at only modest expense, and by purchasing only some hundred volumes, build himself a study that is sufficiently equipped for all kinds of reading. ${ }^{43}$

Testifying to the enduring function of such semi-public, scholars' libraries, the Encyclopédie article 'Livre' referenced the expression 'livre de bibliothèque' as denoting the few works, such as dictionaries, that it was indispensable to have in one's own library. ${ }^{44}$ The bibliothèque choisie, in other words, needs to be

43 François de La Mothe Le Vayer, 'Lettre sur les moyens de dresser une bibliothèque d'une centaine de livres seulement', in CEuvres (Paris: Augustin Courbé, 1654), vol. 2, p. 454.

44 'Livre', in Encyclopédie, ou dictionnaire raisonné des sciences, des arts et des métiers, vol. 9 (1765), p. 6o3. Cf. Leibniz's 'idea of the bibliothèque à sa phantasie, an ideal library ... which should only include two categories of books: first, those containing inventions, demonstrations, and experiences, and second, books of a political, historical, or geographical nature.' Margherita Palumbo, 'Leibniz as librarian', in The Oxford handbook of Leibniz, ed. Maria Rosa Antognazza (Oxford: Oxford University Press, 2018), p. 613. 
understood at all times in relation to other collections of books and libraries, both nominally 'private' and 'public', available to readers, or as part of a larger bookscape - to use James Raven's productive concept - providing readers access to books and print culture through multiple conduits, including libraries, family relations, reading societies and other institutions. ${ }^{45}$

As La Mothe Le Vayer's remarks remind us, despite the supposedly 'personal' character of the bibliothèque choisie, this was also an ideal library anchored in a specific physical and intellectual community. The implied audience described in library manuals potentially constituted a European-wide, 'common reading culture' - with the term 'common' denoting not the social origin of the book readers, but a shared intellectual horizon. Addressing his new edition of the Bibliothèque d'un homme de goût in 1808 to 'men of taste of all countries', Antoine-Alexandre Barbier thus referenced not the finest editions of the works recommended, since these would be of interest primarily to collectors, but rather, 'those articles whose price is nearest to common abilities.' ${ }^{46}$ Both the notions of a supranational interpretive community and of 'common abilities' signal the coalescence in the eighteenth century of groups of individual readers into larger, imagined communities, as Cheryl Knott has argued in discussing what she terms 'common knowledge', or 'both the books held in common by the members of a social library and thus readily accessible to a specific group of people, and the books held in common across libraries and thus capable of helping distant citizens see themselves as part of a whole: ... local, national, transnational or some combination.:47 Put slightly differently, eighteenth-century library manuals might, similarly, be considered as creating a set of shared values uniting readers across regions, across professional or social groups, and perhaps even across confessional boundaries, thereby shaping a common intellectual culture around the federating concept of the bibliothèque choisie.

45 James Raven, Bookscape: Geographies of printing and publishing in London before 1800 (London: The British Library, 2014). See also, on the multiple forms of engagement with print culture in eighteenth-century Britain, Abigail Williams, The social life of books: Reading together in the eighteenth-century home (New Haven: Yale University Press, 2017).

46 Barbier and Des Essarts, Nouvelle Bibliothèque d'un homme de goût, vol. 1, p. xv.

47 Cheryl Knott, 'Uncommon knowledge: Late eighteenth-century American subscription library collections', in Mark Towsey and Kyle B. Roberts (eds.), Before the public library: Reading, community, and identity in the Atlantic world, 1650-1850 (Leiden: Brill, 2018), p. 15 . 


\section{Samuel Formey's Conseils pour former une bibliothèque (1746-1764)}

The most widely reprinted eighteenth-century library manual, and the one which most forcefully engaged with the concept of the bibliothèque choisie, was undoubtedly Jean Henri Samuel Formey's Conseils pour former une bibliothèque peu nombreuse mais choisie. Showcasing the bibliothèque choisie in its title, this manual has been studied as influencing processes of canon-formation in mid-eighteenth-century Europe, and as a key publication in 'the development of this kind of text into a pedagogical instrument with an enculturating function (Bildungsfunktion)'.48 Its author, the Prussian-born Huguenot Samuel Formey, was a central figure in the eighteenth-century literary and cultural field. An enormously productive polymath, he stands out both for his multiple, well-documented relations with major intellectual figures across Europe, for his work as editor of a dozen review journals, and for his authorship of a number of successful, popularising works, especially on the natural theology of the German philosopher Christian Wolff, that attempted to reconcile Enlightenment ideas with a religious worldview. As perpetual secretary of the Berlin Academy of Sciences, Formey was much sought-after for his connections in the Republic of Letters, and he maintained relations with dozens of publishers (including 42 in the German states, 18 in the Dutch Republic and 7 in Switzerland), among them some of the most important of the period, such as the Luchtmans family in Leiden and Antoine-Claude Briasson in Paris. ${ }^{49}$

Written at the instigation of the minister Ludwig Wilhelm Graf von Münchow, who had asked him to draw up a list of books with which every private citizen should be familiar, Formey's Conseils met with considerable success: the first edition in 1746 was followed by four other new, substantially revised editions, in 175 o, 1755,1756 and 1764 , and possibly more. ${ }^{50}$ One of these,

48 Annett Volmer, 'Lektüre, Bildung, Wissenkanon: Jean-Henri-Samuel Formeys Ratschläge zum Aufbau einer Privatbibliothek im 18. Jahrhundert', in Sandra Pott, Martin Mulsow and Lutz Danneberg (eds.), The Berlin refuge 1680-1780: Learning and science in European context (Leiden: Brill, 2003), p. 184.

49 Jan Schillings, 'Nouvelle Bibliothèque germanique, 1746-1760, een atypisch geleerdentijdschrift', De Achttiende Eeuw, 34 (2002), note 39.

50 Rolf Geissler identifies seven editions, with extant copies in libraries in Paris and Berlin, and two additional editions cited elsewhere. Content-wise, I distinguish only five editions, since the second editions he lists in 1746 and 1756 are quasi-identical reissues of the same text. Rolf Geissler, 'Bibliographie des écrits de Jean Henri Samuel Formey', in La Correspondance de Jean Henri Samuel Formey (1711-1797): inventaire alphabétique, ed. Jens Häseler (Paris: Champion, 2003), p. 429. 
the 1756 edition, was the work not of Formey, but of his Paris publisher Briasson, as I discuss below. ${ }^{51}$ The 1764 edition was most likely due to an unidentified compiler. ${ }^{52}$ These five editions differ in length, in the new preface Formey wrote for each edition, and in the list of book recommendations, that was likewise updated for each successive edition. While the first edition of Formey's text listed 593 titles that should figure in the bibliothèque choisie, by the last edition authorised by Formey, in 1755, the number had grown to 713 , or a $20 \%$ increase. The growth in titles is larger still in the last, probably non-authorised edition, published in 1764 , that listed 839 titles, or a $41 \%$ increase relative to the original edition.

Formey's Conseils is a key text because in it, two traditions come together: on the one hand, the tradition of the scholarly, universal library, divided into the traditional categories, with theology in pride of place at the beginning of the list; and on the other hand, the new ideal of the bibliothèque choisie or library of 'private' reading, with an increased focus on belles-lettres. The universal ideal was reflected not in the number of books recommended, but in the prominent place accorded to encyclopaedias, dictionnaires (including those of Moréri and Bayle) and other kinds of compendia, and including also review journals, to which Formey dedicated an entire subject category section: conspicuous among the latter were complete runs of all three of Le Clerc's Bibliothèques. Yet at the same time, the bibliothèque choisie-inflected change of content in the books proposed, coupled with the instructional, popularising aims common to most eighteenth-century library manuals, were also foregrounded in successive editions, and consolidated in the final edition published by Schneider in Amsterdam in 1764. Bringing together both La Martinière's earlier, tone-setting Instructions and Formey's opuscule, this edition targeted a new audience, as the first part of a projected eight-part series titled La Bibliothèque du jeune citoyen compiled 'for the instruction of young people', and comprising volumes on history, geography, philosophy and literature.

$5^{1}$ Jean Henri Samuel Formey [and Antoine-Claude Briasson], Conseils pour former une bibliothèque peu nombreuse mais choisie. Nouvelle édition corrigée et augmentée, suivie de l'Introduction Générale à l'Etude des Sciences et Belles-Lettres, par M. de La Martinière (Berlin: Haude \& Spener [= Paris, Antoine-Claude Briasson], 1756).

52 Antoine-Augustin Bruzen de La Martinière and Jean-Henri Samuel Formey, Introduction Générale aux sciences avec les conseils pour former une bibliothèque peu nombreuse mais choisie. Augmentée d'un article des livres de commerce (Amsterdam: Schneider, 1764) 


\section{Library Manuals, Auction Catalogues and Hierarchies of Knowledge}

The five different editions of Formey's Conseils are significant not only as an indicator of the commercial success of this library manual, but also for what they reveal about changing knowledge organisation systems. In his analysis of another library manual inspired by Formey's, Dirk Werle has argued that these books reveal how 'the space of learned knowledge - in the literal and metaphorical sense - is reorganized around the middle of the eighteenth century.'53 Indeed, as the veteran philosopher-librarian Gottfried Wilhelm Leibniz underlined throughout his long career, announcing some of the fundamental discussions that would mark the Enlightenment period, there were 'two aspects of a unitary problem', namely the relation between 'de ordinatione librorum (the order of books) and de ordinatione cognitionum (the order of knowledge). ${ }^{54}$ The eighteenth-century reorganisation of knowledge manifested itself in many places, including, at a most prosaic level, in the headings Formey adopted to categorise books. Like books in auction catalogues, lists of books presented in library manuals were organised according to various classification systems. Yet despite the prevalence of the Parisian booksellers' system in other bibliographic publications, none of the eighteenth-century library manuals fully implemented it, as a comparison of the categorisation schemas in three manuals makes clear (Table 15.4). The oldest of these texts, La Mothe Le Vayer's, followed the Parisian division into five main categories most closely, with his categories II (theology), vI (law), v (history) corresponding to 'Religion', 'Law' and 'History' respectively, categories I (dictionaries) and IV (poets) mapping onto 'Belles-lettres', and the remaining categories fitting into the catch-all category 'Arts and sciences'. A century later, by contrast, a categorisation system such as Chaudon's in 1772 testified to a more fundamental reorganisation of knowledge systems, exemplified elsewhere in society by the Encyclopédie's novel ways of thinking about the 'natural' order of ideas. As Leibniz had also pointed out in his posthumous Nouveaux essais sur l'entendement humain (1765), that provided important inspiration to the generation of French Encyclopédistes, just as a book can be shelved in different places in a library, so could the same truth belong to different series according to the

53 Dirk Werle, 'Umbau des polyhistorischen Wissenraums. Johann Christoph Stockhausens Critischer Entwurf einer auserlesenen Bibliothek für den Liebhaber der Philosophie und schönen Wissenschaften (1752)', Berichte zur Wissenschaftsgeschichte, 34 (2011), p. 125.

Palumbo, 'Leibniz as librarian', p. 619. 
different relations in which it could be envisaged. ${ }^{55}$ No categorisation system, in other words, was completely stable. Building on the Encyclopédie's radical reorganisation of the tree of knowledge, Chaudon's manual broke altogether with the traditional prominence of theology as queen of the sciences, and focused squarely instead on the vast category of 'Belles-lettres', that was the primary subject discussed in his library manual.

TABLE 15.4 Subject categorisation of books in three library manuals, 1654-1772

\begin{tabular}{lll} 
La Mothe Le Vayer $\mathbf{1 6 5 4}$ & Formey $\mathbf{1 7 4 6}$ & Chaudon $\mathbf{1 7 7 2}$ \\
\hline Dictionnaires \& Lexicons & Ecriture sainte, Théologie \& & Poètes anciens \\
& Histoire Ecclésiastique & \\
Théologie & Philosophie & Poètes étrangers \\
Médecine & Belles Lettres & Poètes français \\
Mathématiques & Journaux & Poétique \\
Histoire & Histoire & Orateurs anciens \& modernes \\
Droit Civil \& Canon & Romans & Rhétorique \\
Rhétorique \& Orateurs, Poètes & Poésie & Chronologie \\
Métiers & Eloquence & Histoire sacrée \& ecclésiastique \\
Histoire naturelle de Pline & Morale \& Goût & Histoire \\
& Science militaire \& & Ouvrages périodiques \\
& Mathématiques & Politique \& droit public \\
& Géographie \& Voyages & Jurisprudence \\
& Jurisprudence \& Médecine & Médecine, botanique, chimie \&c. \\
& & Commerce \\
& & Philosophie \\
& & Religion \\
\hline & & Morale \\
& & Art militaire \\
& & Jardinage \& agriculture \\
& & Facéties, anecdotes \& bons mots
\end{tabular}

55 Claire Fauvergue, 'Pensée sérielle et pensée encyclopédique: l'esprit de combinaison et l'ordre naturel des idées chez Leibniz et les encyclopédistes', in Anne-Marie De Gendt and Alicia C. Montoya (eds.), La pensée sérielle, du Moyen Age aux Lumières (Leiden: Brill Rodopi, 2019), p. 244. 
Somewhere between the two extremes of fidelity to the conventional Parisian booksellers' system on the one hand, and the creation of new classification systems on the other, lay Formey, again bridging the conceptual gap between the intellectual models represented by the bibliothèque universelle and the bibliothèque choisie. In his classification system (Table 15.5), religion still held pride of place as the first of the categories listed, but the relative importance of books relating to 'Belles-lettres' was also evident. Instead of the traditional five major categories, Formey distinguished twelve different headings, in some cases also mixing categories that had previously been kept apart ('Jurisprudence \& Médecine'). His most radical innovation was, however, a return to one of the previous, discarded iterations of the Parisian system, by the Jesuit Jean Garnier: the creation of a separate category for 'Philosophie', no longer conceived as a subdivision of 'Arts et sciences. ${ }^{56}$ Significantly, this autonomous category followed directly upon 'Théologie', implying a possible re-evaluation of the relative merits and position of the two fields of knowledge.

TABLE 15.5 Subject categorisation in editions of Formey's Conseils, and number of titles per category

\begin{tabular}{|c|c|c|c|c|c|}
\hline & 1746 & $175^{\circ}$ & 1755 & $175^{6}$ & 1764 \\
\hline $\begin{array}{l}\text { Ecriture sainte, Théologie \& Histoire } \\
\text { Ecclésiastique }\end{array}$ & 46 & $5^{\circ}$ & $5^{1}$ & 32 & $5^{6}$ \\
\hline Philosophie & 39 & 42 & 54 & 57 & 59 \\
\hline Belles-lettres & 65 & 68 & 74 & 86 & 82 \\
\hline Journaux & 18 & 18 & $3^{\circ}$ & 25 & $3^{\circ}$ \\
\hline Histoire & 66 & 70 & 74 & 84 & 82 \\
\hline Romans & 67 & 69 & 79 & 85 & 87 \\
\hline Poésie & 84 & 91 & 91 & 96 & 94 \\
\hline Eloquence & 18 & 18 & 19 & 18 & 23 \\
\hline Morale \& goût & 74 & 80 & 91 & 88 & 96 \\
\hline Science militaire \& mathématiques & 44 & 55 & 57 & 62 & 76 \\
\hline Géographie \& Voyages & 45 & 49 & $5^{2}$ & $5^{1}$ & 55 \\
\hline Jurisprudence \& Médecine & 27 & 33 & 41 & 48 & 59 \\
\hline Commerce & - & - & - & - & 40 \\
\hline Total & 593 & 643 & 713 & 732 & 839 \\
\hline
\end{tabular}

$5^{6}$ Jean Garnier, Systema Bibliothecae Collegii Parisiensis Societatis Jesu (Paris: Sebastien Mabre-Cramoisy, 1678). 
As Simon Burrows has discussed in a chapter on 'Troubling taxonomies' in his French Book Trade in Enlightenment Europe, building on a point raised before him by Robert Darnton, it was at this particular junction - the relation between the categories 'Religion' and 'Philosophy', conventionally conceived as a subcategory of 'Arts and Sciences' - that the Parisian booksellers' system threatened to break down. The range of subjects categorised as 'Arts and sciences', embracing both the applied sciences as well as works of philosophy, was disconcerting. In addition, 'Philosophy' could move disturbingly close to 'Religion' when it included heterodox works associated with the radical Enlightenment movement. ${ }^{57}$ Formey's choice to make 'Philosophy' follow directly upon 'Ecriture sainte, Théologie \& Histoire Ecclésiastique' could be perceived either as a purely practical solution to this problem, or as a possible intellectual standpoint, that made use of a restructuring of knowledge organisation systems as a means to rethink the position of philosophy in the hierarchy of knowledge - as the Encyclopédie authors would, more radically still, by subsuming 'Theology' under 'Philosophy' just a few years later.

The competing claims made on educated readers by theology and religion are illustrated most tellingly by the non-authorised edition of Formey's Conseils that was published in Paris by Antoine-Claude Briasson in 1756, under the false imprint of Haude \& Spener. Briasson is known to historians today primarily as one of the publishers of Diderot and d'Alembert's Encyclopédie, that revolutionised knowledge organisation systems with its tripartite division into Memory (History), Reason (Philosophy) and Imagination (Poetry). ${ }^{58}$ Briasson and Formey had a long-standing relationship, that went back to 1738, and included Formey's proposal in 1742 to publish a philosophical encyclopaedia titled Dictionnaire philosophique with Briasson. Although Briasson initially showed interest in the project, he withdrew when he became involved in a rival project, that of translating Ephraim Chamber's Cyclopedia in French, that eventually evolved into the French Encyclopédie. With Briasson's help, Formey did however sell his unused material - 114 articles in all - to the Encyclopédie authors, who included them in their final, epoch-making publication. ${ }^{59}$

57 Simon Burrows, The French book trade in Enlightenment Europe, II. Enlightenment bestsellers (London: Bloomsbury, 2018), pp. 8o-81.

$5^{8} \quad$ Frank A. Kafker and Jeff Lowland, 'Antoine-Claude Briasson et l'Encyclopédie', Recherches sur Diderot et sur l'Encyclopédie, 35 (2003), pp. 131-139.

59 Annelie Grosse, 'Christian philosophy in the Enlightenment's flagship encyclopedia: Jean Henri Samuel Formey's unfinished philosophical encyclopedia (1742-1747) as a source of the Encyclopédie', forthcoming. In his Conseils, Formey whetted his readers' appetite for the yet unpublished Encyclopédie, announcing in $175^{\circ}$ that a French translation of Chamber's Cyclopedia was currently in press. Formey, Conseils [1750], p. 18. 
As the Encyclopédie was getting underway, with the first volume just published in 1751, Briasson suggested to Formey that he produce a revised version of his Conseils, adapted to French taste, as a supplement to his Système du vrai Bonheur. ${ }^{60}$ The suggestion apparently did not elicit a reply, but then in 1755 , Briasson revealed that he had gone ahead with the plan anyway and was preparing a substantially revised edition of Formey's work, unbeknownst to the author, for the French market. Writing that the Berlin edition paid too much attention to 'foreign works, others that have since been updated, and others of a different confession than our own,' Briasson argued that 'it seemed to me that it would only sell better if turned to the usage of us Frenchmen.' There were further commercial motives, as Briasson was forced to admit: 'I have also acted on another motive: my book business is dear to me and I have cited many of my books without affectation but always with the aim of indicating them according to your plan and your tone. ${ }^{61}$ Briasson reiterated his intent to use this publication as a vehicle to promote his own unsold stock in a subsequent letter, in which he suggested the Conseils might function much like an auction catalogue, 'as a book catalogue that could be distributed, often even for free,' in order to encourage customers to buy the books described in it. ${ }^{62}$

Despite these stated commercial motives, a closer examination of the 1756 edition shows however that there was also an intellectual dimension to the changes made by Briasson. To Formey's text, Briasson added that of La Martinière's Introduction générale à l'étude des sciences, thereby underlining the Frenchman's earlier claim to the concept of the bibliothèque choisie and the related genre of the library manual. But it was especially in the categories 'Théologie' and 'Philosophie' that this edition of Formey's text differed most markedly from the original. There was a dramatic decrease in the number of theology books, which fell from $5^{1}$ to 31 titles. This was due only in part to Briasson's omitting titles whose Protestant origin would have displeased his Catholic readers. In the category 'Eloquence', the number of sermon collections was similarly halved. There was also a perceptible shift of tone in the discussion of books labelled 'Philosophie'. Formey's criticism of the progressive abbé Raynal's work, for example, was rewritten by Briasson and turned into a more favorable assessment. References to German publications defending Wolffian philosophy, with its reconciliation of reason and faith, were omitted

6o Briasson to Formey, 28 May 1751. Correspondance passive de Formey. Briasson et Trublet (1739-1770), ed. Martin Fontius, Rolf Geissler and Jens Häseler (Paris: Champion, 1996), p. 67 .

61 Briasson to Formey, 6 May 1755. Correspondance passive, p. 83.

62 Briasson to Formey, 11 August 1755. Correspondance passive, p. 85. 
altogether. Once again, intellectual and commercial interests intersected, producing a volume that combined the bookseller's practical considerations with the author's stated purpose of describing the ideal bibliothèque choisie, reconceptualised now in light of more general questions relating to knowledge organisation and popularisation in the mid-eighteenth century.

Returning now to Formey's classification scheme, it might be expected that evolving ideas about the hierarchy of knowledge might also be reflected in differences in the relative attention he paid to book subject categories. Yet despite the changes made by Formey to the conventional categorisation schema, it is still relatively straightforward to crosswalk his system to the schema of the Parisian booksellers (Table 15.6). Thus his categories III (belles-lettres), IV (journals), VI (novels) and VII (poetry) can easily be fit into the category 'Belles-lettres'. Category I corresponds directly to 'Religion', while categories II (philosophy) and $\mathrm{x}$ (military science) correspond to 'Arts and sciences', and $\mathrm{v}$ (history) and XI (geography) to 'History'. The only, very slight difficulties present themselves in category viII (eloquence), which was made up largely but not exclusively of sermons, and the last, mixed category XII (law and medicine) that combined titles from two distinct categories that the booksellers' system kept separate.

The differences remain relatively modest, from edition to edition of Formey's Conseils, but do produce a cumulative effect over time, with changes in successive editions taking place through a process of accumulation rather than subtraction of titles - with the exception, that is, of Briasson's edition. Only seven titles from the original edition did not make it into the final, 1764 edition of the Conseils, while 253 new titles were added. Overall, there is an increase in the number and proportion of books classified in the category 'Arts and sciences' which included besides philosophy, also a new category introduced in the 1764 edition, commerce. There is a corresponding, very slight decrease in the other

TABLE 15.6 Subject categorisation in five editions of Formey's Conseils

\begin{tabular}{lrrrrr}
\hline Subject category & $\mathbf{1 7 4 6}$ & $\mathbf{1 7 5} \%$ & $\mathbf{1 7 5 5}$ & $\mathbf{1 7 5 6}$ & $\mathbf{1 7 6 4}$ \\
\hline Religion & $10 \%$ & $10 \%$ & $9 \%$ & $6 \%$ & $9 \%$ \\
Law & $3 \%$ & $3 \%$ & $4 \%$ & $4 \%$ & $5 \%$ \\
History & $19 \%$ & $19 \%$ & $18 \%$ & $18 \%$ & $16 \%$ \\
Belles-lettres & $49 \%$ & $48 \%$ & $47 \%$ & $49 \%$ & $43 \%$ \\
Arts and sciences & $16 \%$ & $17 \%$ & $18 \%$ & $20 \%$ & $24 \%$ \\
Other ('Journaux') & $3 \%$ & $3 \%$ & $4 \%$ & $3 \%$ & $3 \%$ \\
\hline
\end{tabular}


categories, which is most noticeable in the category 'Belles-lettres' - although in absolute numbers, the numbers of books in this category actually grew, from 291 in 1746 to 36 o in 1764 . The decrease in the proportion of books assigned to the category 'Religion' is slight, and in this case again, masks an actual increase in absolute numbers, from 61 in 1746 to 72 in 1764

\section{Comparative Approaches to Book Subject Distribution}

Did these eighteenth-century changes in the hierarchy of knowledge and 'troubling taxonomies' have a direct impact on real libraries in the eighteenth century? In order to answer this question, I turn now to a corpus of library auction catalogues that are currently being mined for their book data as part of the European Research Council-funded mediate project (Measuring Enlightenment: Disseminating Ideas, Authors, and Texts in Europe, 16651840). This project uses existing inventories to create a digital corpus that will total, in the long term, 2,000 catalogues of private libraries sold at auction between 1665 and 1840, in France, Italy, the Dutch Republic and British Isles. For the Dutch catalogues, the project draws primarily on the corpus of auction catalogues originally collected by the late Bert van Selm and his collaborators, and now digitised as Brill's Book Sales Catalogues Online. Because of its conceptual focus on 'common' reading, the MEDIATE project prioritises the transcription and data enrichment of book data drawn from smaller and mid-size catalogues, defined as those catalogues comprising 1,00o or fewer book lots, and representing the lower half or about $50 \%$ of the total corpus of extant private library auction catalogues. ${ }^{63}$ Given this focus on smaller collections, that by definition do not belong to the class of universal or comprehensive libraries, this corpus provides material to test the relevance of the concept of the bibliothèque choisie. For the following, I therefore draw on a sample of 70 catalogues of Dutch private libraries sold at auction in the period 1700-1800, for which the MEDIATE project has compiled basic data on the subject categorisation of the books listed. In order to ensure the usability of the data for comparative purposes, the 70 catalogues were picked with an eye to an even distribution across the century, with 35 catalogues dating from the period $1701-175^{\circ}$, and 35 dating from the period $175^{1-1800 .}{ }^{64}$ This corpus is hence not, strictly

63 As calculated by Rindert Jagersma in his contribution to this volume: see chapter four, above.

64 These are, in chronological order: Bloemendael 1701; Arl 1703; Loosdrecht 1704; Goyer 1706; Scherpezeel 1707; Streso 1708; Hellius 1709; Holtenus 1710; Bogaart 1711; Gürtler 1712; 
speaking, representative, since relatively more Dutch catalogues were produced and have been preserved from the earlier period than from the later part of the eighteenth century. In addition, the corpus has other biases that may make it a less than ideal sample against which to test the historical reality of the bibliothèque choisie. Most importantly, while the concept of the bibliothèque choisie was most fully developed in the French-speaking world, these are Dutch catalogues, with a relatively strong Latinate content - certainly when compared to contemporary French catalogues - and a strong focus on local debates and intellectual traditions. Given the lack of a reliable overview of the catalogues produced in France, a lacuna that the MEDIATE project is working to remedy, this is the most usable sample currently available. While it would be tempting to draw on other, more famous French auction catalogue datasets that have been previously used for comparative bibliometric purposes, these datasets proved for various reasons to be unsuited to my purposes. ${ }^{65}$

Ede 1714; Hagen 1715; Rooseboom 1717; Sismus 1719; Colyn 1720; Edens 1721; Wallendal 1723; Cocq 1724; Desmarets 1725; Schulting 1726; Savoys 1727; Verryn 1728; Rantre 1730; Walkart 1731; Brandwyk 1733; Brugman 1734; Ouburg 1735; Glay 1736; Feilingius 1739; Nokken 1741; Oosterdijk 1744; Marck 1747; Schaak 1748; Pedecoeur 1749; Pauw 1750; Rheenen 1751; Sautyn 1752; Peregrinus 1754; Borcht 1755; Reeder 1757; Satinck 1758; Dorp 176o; Hellegers 1762; Fruytier 1763; Sluiter 1764; Edens 1765; Touns 1767; Marck 1768; Bolle 1769; Snip 1771; Staveren 1772; Alting 1774; Macaré 1775; Hasselaer 1776; Vaassen 1777; Marcus 1780; Smidt 1781; Mettivier 1782; Schomaker 1783; Schouten 1784; Ghysels 1785; Lichtenbergh 1786; Wallen 1789; Kops 1791; Arrest 1792; Bekker 1794; Mandere 1795; Husly 1798; Markon 1799; and Boullier 1800 .

65 Daniel Mornet's study of 5 oo French library auction catalogues, that has been widely cited as providing an accurate overview of book distribution across subject categories in a corpus of 5 oo catalogues, turned out to offer incomplete data. Not only did Mornet base his calculations on a system of averaged-out percentiles rather than precise totals, he also used different sample sizes - never the full 500 - per category, for example using 376 catalogues to calculate Theology, but only 62 catalogues for Medicine (with no indication of which catalogues, rendering the study impossible to replicate). He also undercounted some categories. Thus in 'Belles-lettres' he included novels and grammar books, but left out other genres such as theatre and poetry. Similarly, he left out philosophy, among others, from 'Arts et sciences', making his proportions unusable for comparative purposes. Daniel Mornet, 'Les enseignements des bibliothèques privées (1750-1780)', Revue d'histoire littéraire de la France, 18 (1910), pp. 449-496. For later uses of Mornet's data, see Robert Darnton's chart 'Patterns of reading in mid-eighteenth century France', in 'Reading, writing and publishing in eighteenth-century France: A case study in the sociology of literature', Daedalus, 100 (1971), p. 224, reproduced in his Literary underground of the Old Regime (Cambridge: Harvard University Press, 1985), pp. 167-208, and - with additional data - in Burrows, The French book trade, p. 92. Other datasets, for example recording the contents of French magistrates' libraries, were unsuited to our purposes because of their focus on a specific occupational group, whose professional obligations heavily influenced their library content. 
In this corpus of 70 auction catalogues, the booksellers drawing up the catalogues classified all books by format, and in some cases, by language. Only 28 of the catalogues, however, offer at least some form of subject categorisation. This contrasted with French library auction catalogues, that much more frequently carried some form of subject classification. The Dutch booksellers' subject classification was often a functional, minimal categorisation: most frequently, a simple bipartite division, encompassing the single largest subject category in a particular collection, on the one hand, and a category of 'Miscellanei' on the other. This bipartite system is the format followed by auction catalogues such as those of the library of the Remonstrant minister Eduardus Holtenus, sold in 1710, and the Franeker Professor of philosophy Nicolaus Gürtler, sold in 1712 (the two categories being 'Theologici' and 'Miscellanei'), or Frederik Rooseboom, justice in the Court of Holland, whose library was auctioned in 1717 ('Juridici', 'Miscellanei'). In a few cases, a bipartite division may alternatively be an indication that the collection was incomplete, as the books being auctioned may have represented only one part of a larger library.

Of these 70 Dutch auction catalogues, only 12 , or $17 \%$, had categorisation systems comprising at least three of the five traditional subject categories. Only four catalogues used all five categories. Even when they did use all five categories, the percentage of books relegated to a category of 'Miscellanei', to a language category ('Livres françois', 'Libri anglici') or a combination category so wide-ranging as to be conceptually meaningless, such as 'Antiquarii, Historici, Literatores, Miscellanei, ut \& Theologici \& Juridici, in Quarto' (Staveren 1772), was considerable, sometimes as high as $49 \%$ (Schulting 1726 ) or a staggering $100 \%$ (Staveren 1772 ). ${ }^{66}$ The 12 catalogues that did use some or all of the Parisian subject categories described libraries belonging to a population of owners made up overwhelmingly of government officials and solicitors. These accounted for six collections (Abraham d'Arrest, Joh. Bernh. Marck, Jan Joost Marcus, Constantin Sautyn, Johannes Schulting and Pieter van Dorp). In addition, the corpus includes one church minister (Paulus Verryn), one physician (J. Walkart), one philologist (Joannes Cornelius de Pauw), one grammar school headmaster (Jacques van Vaassen), the widow of a prominent man of letters (widow Markon), and one man with an unknown profession (Gerard Schaak). A large proportion - five of the catalogues - were produced by a single booksellers' family, the Amsterdam bookseller Salomon Schouten and his successors, either working alone (1726), with Adriaan Slaats (1728), with his son Petrus (1748), or after Salomon's own death, Petrus Schouten and Salomon's

66 Catalogues are designated by the owner's surname followed by the year of auction, with full catalogue metadata available in the вsco database. 
widow (1752) and later Petrus alone (1780). According to Isabella van Eeghen, Salomon Schouten made a name for himself in the eighteenth century as the most important Amsterdam auctioneer of his day, and the evidence from the catalogues suggests that he took some pride in organising his catalogues according to internationally accepted systems. ${ }^{67}$

For the purposes of testing the historical validity of concepts of the bibliothèque choisie, I focused on the corpus of 28 catalogues that offered some form of subject classification, since this was suggestive of at least minimal reflection - if only on the part of the bookseller - on the intellectual choices underlying the library contents. In order to determine the proportions of book lots that could be assigned to each of the five booksellers' categories in this corpus, I subject-classified all books, including those assigned by booksellers to the various 'Miscellanea', language and mixed categories, to produce an overview of the subject distribution in these catalogues (Table 15.7).$^{68}$

Overall, it is clear that the relative importance of subject categories changed as the century progressed. These changes are visible at an aggregate level, rather than at the level of individual catalogues. Splitting the data into two parts, showing the data of the catalogues from the first half of the century, compared to data from the catalogues from after $175^{\circ}$ (Table 15.8) makes these differences quantifiable. As in Le Clerc's review journals and auction catalogues, there is a decline in the proportion of books categorised as 'Religion', that falls from $35 \%$ in the first half of the eighteenth century to $30 \%$ in the second half. This decrease is offset by an increase in the proportion of books categorised 'Belles-lettres', that jumps from $16 \%$ to $22 \%$. There is also a slight increase in numbers in the category 'Arts and sciences', that passes from $8 \%$ to $10 \%$. The increased prominence of the category of 'Belles-lettres' is evident, further, in the distribution across the century of the libraries in which it is the numerically most important subject category. While in the first half of the eighteenth century, the most popular category is 'Religion', with half of the libraries having it as their largest category, in the second half of the century it is replaced by 'Belles-lettres' as the category that most often dominates private library holdings - in five cases - while 'Religion' now takes second place.

67 Isabella Henriëtte van Eeghen, De Amsterdamse boekhandel 1680-1725, deel 4. Gegevens over de vervaardigers, hun internationale relaties en de uitgaven $N-W$, papierhandel, drukkerijen en boekverkopers in het algemeen (Amsterdam: Scheltema \& Holkema, 1967), p. 119. The original data can be consulted in the MEDIATE database, available online from early 2022: www.mediate18.nl. 
TABLE 15.7 Subject categorisation of book lots in 28 Dutch auction catalogues

\begin{tabular}{|c|c|c|c|c|c|c|}
\hline & Religion & Law & History & $\begin{array}{l}\text { Arts and } \\
\text { sciences }\end{array}$ & $\begin{array}{l}\text { Belles- } \\
\text { lettres }\end{array}$ & Unclassified $^{\mathrm{a}}$ \\
\hline Loosdrecht 1704 & $10 \%$ & $22 \%$ & $31 \%$ & $14 \%$ & $13 \%$ & $10 \%$ \\
\hline Goyer 1706 & $5 \%$ & $19 \%$ & $28 \%$ & $4 \%$ & $28 \%$ & $16 \%$ \\
\hline Holtenus 1710 & $44 \%$ & $1 \%$ & $22 \%$ & $4 \%$ & $16 \%$ & $13 \%$ \\
\hline Gürtler 1712 & $58 \%$ & $1 \%$ & $20 \%$ & $6 \%$ & $7 \%$ & $8 \%$ \\
\hline Ede 1714 & $56 \%$ & $1 \%$ & $19 \%$ & $3 \%$ & $12 \%$ & $9 \%$ \\
\hline Roseboom 1717 & $23 \%$ & $18 \%$ & $35 \%$ & $5 \%$ & $9 \%$ & $10 \%$ \\
\hline Schulting 1726 & $9 \%$ & $25 \%$ & $22 \%$ & $3 \%$ & $24 \%$ & $17 \%$ \\
\hline Verryn 1728 & $57 \%$ & $1 \%$ & $12 \%$ & $8 \%$ & $20 \%$ & $2 \%$ \\
\hline Walkart 1731 & $26 \%$ & $5 \%$ & $11 \%$ & $28 \%$ & $13 \%$ & $17 \%$ \\
\hline Feilingius 1739 & $63 \%$ & $2 \%$ & $9 \%$ & $5 \%$ & $14 \%$ & $7 \%$ \\
\hline Oosterdijk 1744 & $76 \%$ & $<0.05 \%$ & $8 \%$ & $4 \%$ & $6 \%$ & $6 \%$ \\
\hline Marck 1747 & $35 \%$ & $25 \%$ & $15 \%$ & $12 \%$ & $8 \%$ & $5 \%$ \\
\hline Schaak 1748 & $18 \%$ & $6 \%$ & $45 \%$ & $9 \%$ & $17 \%$ & $5 \%$ \\
\hline Pauw $175^{\circ}$ & $12 \%$ & $16 \%$ & $25 \%$ & $7 \%$ & $36 \%$ & $5 \%$ \\
\hline Rheenen $175^{1}$ & $19 \%$ & $1 \%$ & $14 \%$ & $43 \%$ & $13 \%$ & $10 \%$ \\
\hline Sautyn $175^{2}$ & $10 \%$ & $37 \%$ & $25 \%$ & $11 \%$ & $10 \%$ & $7 \%$ \\
\hline Dorp 176o & $27 \%$ & $34 \%$ & $21 \%$ & $3 \%$ & $11 \%$ & $4 \%$ \\
\hline Marck 1768 & $72 \%$ & $1 \%$ & $9 \%$ & $2 \%$ & $8 \%$ & $8 \%$ \\
\hline Staveren 1772 & $11 \%$ & $2 \%$ & $25 \%$ & $3 \%$ & $46 \%$ & $13 \%$ \\
\hline Alting 1774 & $76 \%$ & $1 \%$ & $11 \%$ & $3 \%$ & $5 \%$ & $4 \%$ \\
\hline Vaassen 1777 & $2 \%$ & $20 \%$ & $26 \%$ & $<0.05 \%$ & $42 \%$ & $10 \%$ \\
\hline Marcus 1780 & $21 \%$ & $17 \%$ & $23 \%$ & $9 \%$ & $19 \%$ & $11 \%$ \\
\hline Smidt 1781 & $76 \%$ & $<0.05 \%$ & $6 \%$ & $4 \%$ & $10 \%$ & $4 \%$ \\
\hline Lichtenbergh 1786 & $29 \%$ & $15 \%$ & $25 \%$ & $11 \%$ & $15 \%$ & $5 \%$ \\
\hline Kops 1791 & $13 \%$ & $3 \%$ & $27 \%$ & $17 \%$ & $36 \%$ & $4 \%$ \\
\hline D'Arrest 1792 & $11 \%$ & $11 \%$ & $29 \%$ & $15 \%$ & $24 \%$ & $10 \%$ \\
\hline Markon 1799 & $27 \%$ & $11 \%$ & $12 \%$ & $5 \%$ & $43 \%$ & $2 \%$ \\
\hline Boullier 1800 & $28 \%$ & $<0.05 \%$ & $11 \%$ & $11 \%$ & $32 \%$ & $18 \%$ \\
\hline
\end{tabular}

a The category 'Unclassified' includes those lots I was unable to classify either because of lack of sufficient bibliographic detail, because the lot comprised multiple items belonging to different categories, because the book itself had a composite character, or because the book left room for debate on its exact classification - for example, ecclesiastic history (History or Religion?). 
TABLE 15.8 Subject categorisation of books in first and second half of eighteenth century

\begin{tabular}{lcccc}
\hline & $\begin{array}{l}\text { Catalogues } \\
\mathbf{1 7 0 0 - 1 7 5}\end{array}$ & $\begin{array}{l}\text { Catalogues } \\
\mathbf{1 7 5 1 - 1 8 0 0}\end{array}$ & $\begin{array}{l}\text { Formey } \\
\mathbf{1 7 4 6}\end{array}$ & $\begin{array}{l}\text { Formey } \\
\mathbf{1 7 6 4}\end{array}$ \\
\hline Religion & $35 \%$ & $30 \%$ & $10 \%$ & $9 \%$ \\
Law & $10 \%$ & $11 \%$ & $3 \%$ & $5 \%$ \\
History & $\mathbf{2 2} \%$ & $19 \%$ & $19 \%$ & $16 \%$ \\
Arts and sciences & $8 \%$ & $10 \%$ & $16 \%$ & $24 \%$ \\
Belles-lettres & $16 \%$ & $22 \%$ & $49 \%$ & $43 \%$ \\
Other & $9 \%$ & $8 \%$ & $3 \%$ & $3 \%$ \\
\hline
\end{tabular}

There are, however, wide differences between individual collectors. Thus, while the Gorinchem minister Jacobus Oosterdijk's library catalogue in the first half of the century listed $76 \%$ of books in the category 'Religion', Utrecht law graduate Jacob de Goyer's listed only $5 \%$. Such differences often appear related to the professional affiliations of the library owners. Collectors' professions, unsurprisingly, are a good predictor of the category of books most often found in their libraries (Table 15.9). Thus, eight of the nine ministers' libraries in the sample display a distinct preference for religious reading material, accounting for up to $76 \%$ of their total book lots. The only exception to this rule is the library of the pastor of the French-speaking Walloon church in Amsterdam, Jacques Renaud Boullier, whose library, auctioned in 1800 , at the very end of the period studied here, prioritised the category of 'Belles-lettres' ( $32 \%$ of the total holdings) over religion $(28 \%)$. Similarly, lawyers' libraries tend to give pride of place to books on law or history, while the libraries of medical doctors carry a substantial number of books on medicine and natural history.

The overall changes in the proportions of books in each category present a general move, then, toward collections more similar in content to the recommendations made in Samuel Formey's Conseils. These changes are reflected, in addition, by the decreasing size of the libraries in the 28 library corpus. While the libraries in the first half of the eighteenth century averaged 1,066 book lots, those in the second half of the century numbered on average only 827. Likewise, while no collection in the first half of the century numbered fewer than 500 book lots, two did so after 175 . The differences between the two halves of the century, however, are often so small as to be near meaningless. The shift in valuation is most pronounced for the categories 'Religion' and 'Belles-lettres'. In other cases, however, categories may conceal more than 
they reveal. The unclear content of the all-encompassing category 'Arts and sciences', in particular, and as already noted by previous book historians, calls for further critical unpicking in order to determine what shifts were exactly taking place in the composition of libraries, and how these might relate to the concept of the bibliothèque choisie. ${ }^{69}$ Most interesting, perhaps, is the question of the readership of the new category of 'Belles-lettres', since this did not correlate to a single professional group, as the category 'Religion', for example, did to ministers. Table 15.9 shows that the six libraries in which the numerically strongest category of book lots was 'Belles-lettres' belonged to collectors coming from a mix of professional backgrounds. They include one law graduate, one professor of philology, one grammar school headmaster, one minister, one textile merchant, and one widow. The new ideal of the bibliothèque choisie appears, then, at least in this limited sample, to have realised its goal of reaching a broad, professionally-mixed public including both men and women. These were not, for the greater part, scholars building a comprehensive, scholarly library, but 'common' readers participating in a new set of shared cultural practices reflected by their books.

If comparisons at the aggregate level are suggestive, at the level of individual collectors, some library auction catalogues displayed a subject distribution very close indeed to that of Formey's library manuals. This holds, notably, for the 1799 auction catalogue of a library annotated by a contemporary hand as belonging to a 'widow Markon', who I have identified elsewhere as Maria Suzanna Barnaart, the widow of the Leiden man of letters Jan Pauluszoon Markon. ${ }^{70}$ In her catalogue, the proportion of books classified 'Belles-lettres' $(43 \%)$ was exactly identical to the Conseils. Similar proportions obtained, further, in the rubric 'History' (12\% in her library, versus $16 \%$ in the 1764 edition of Formey's manual). While it might be tempting to see in this case, as in that of Maria Leti sixty years earlier, additional evidence for the fundamentally gendered nature of the bibliothèque choisie, some caution - and much further research, as for all hypotheses concerning women's reading in this period - is necessary before any such generalising conclusion can be drawn.

69 Burrows, The French book trade, pp. 8o-81.

70 Alicia C. Montoya and Rindert Jagersma, 'Marketing Maria Sibylla Merian, 1720-180o: Book auctions, gender, and reading culture in the Dutch Republic', Book History, 21 (2018), p. 81. 
TABLE 15.9 Collectors' professions and subject category rankings

Profession

Loosdrecht 1704 Amsterdam lawyer

Goyer 1706

Holtenus 1710

Gürtler 1712

Ede 1714

Roseboom 1717

Schulting 1726

Verryn 1728

Walkart 1731

Feilingius 1739

Oosterdijk 1744

Marck 1747

Schaak 1748

Pauw $175^{\circ}$

Rheenen $175^{1}$

Dorp 1760

Marck 1768

Staveren 1772

Alting 1774

Vaassen 1777

Marcus 178 o

Smidt 1781

Lichtenbergh 1786

Kops 1791

D'Arrest 1792

Markon 1799

Boullier 18 oo
Utrecht law graduate

Utrecht Remonstrant

minister

Franeker professor of philosophy

Leiden Remonstrant

minister

justice at Court of Holland law graduate

Remonstrant minister

medical doctor

Venlo minister

Utrecht minister

Warmond bailiff

unknown (Amsterdam)

classical philologist and author

medical doctor

Amsterdam town clerk

Leiden magistrate

Gouda minister

Leiden school rector

Nijkerk minister

Alkmaar grammar school principal

Amsterdam city official

Mennonite professor of theology

Tholen magistrate

Haarlem textile merchant

Weesp magistrate

Leiden widow

pastor Amsterdam Walloon

church

\section{Most frequent Least frequent}

History (31\%) Religion (10\%)

History $(28 \%) \quad$ Arts \& sciences (4\%)

Religion (44\%) Law (< $0.05 \%)$

Religion (58\%) Law (1\%)

Religion (56\%) Law (1\%)

History $(35 \%) \quad$ Arts \& sciences $(5 \%)$

Law $(25 \%) \quad$ Arts \& sciences $(3 \%)$

Religion (57\%) Law (1\%)

Arts \& sciences (28\%) Law $(5 \%)$

Religion $(63 \%) \quad$ Law $(2 \%)$

Religion $(76 \%) \quad$ Law $(<0.05 \%)$

Religion $(35 \%) \quad$ Belles-lettres $(8 \%)$

History (45\%) Law (6\%)

Belles-lettres (36\%) Arts \& sciences $(7 \%)$

Arts \& sciences (43\%) Law (< $0.05 \%)$

Law $(37 \%) \quad$ Religion (10\%)

Law $(34 \%) \quad$ Arts \& sciences $(3 \%)$

Religion $(72 \%) \quad$ Law $(<0.05 \%)$

Belles-lettres $(46 \%) \quad$ Law $(2 \%)$

Religion $(76 \%) \quad$ Law $(<0.05 \%)$

Belles-lettres $(42 \%) \quad$ Arts \& scienc $(<0.05 \%)$

History $(23 \%) \quad$ Arts \& sciences $(9 \%)$

Religion $(76 \%) \quad$ Law $(<0.05 \%)$

Religion (29\%) $\quad$ Arts \& sciences (11\%)

Belles-lettres (36\%) Law (3\%)

History $(29 \%) \quad$ Law $(11 \%)$

Belles-lettres (43\%) Arts \& sciences (5\%)

Belles-lettres $(32 \%) \quad$ Law $(<0.05)$ 


\section{Real versus Ideal Libraries}

The similarities between the subject distribution in the corpus of Dutch libraries and that of Formey's Conseils raise the question of the possible influence Formey and other proponents of the bibliothèque choisie might have had on real collectors and collecting practices. There is, however, little evidence for a direct influence. Formey's manual is not referenced a single time in the corpus of 70 Dutch private library auction catalogues. Neither, however, are any of the other library manuals I have identified in the present article - including the most famous of them all, Gabriel Naudés older Advis pour dresser une bibliothèque. These titles make a modest showing, too, in the other catalogues currently in the MEDIATE database. In the total corpus of 600 catalogues, Naudé's book appears only five times, twice in French catalogues, and three times in English ones. Formey's appears eight times, seven times in French catalogues, and once in the 1773 auction catalogue of the library of the Hague-based Jewish collector Manuel Lopes Suasso. ${ }^{71}$

On the other hand, these libraries do testify to their owners' bibliographic interests in other ways. Within the corpus of library auction catalogues with some form of subject classification, most - 21 out of 28 - contained one or more books dealing with libraries and their composition, totaling close to a hundred titles. Most of these were printed catalogues of other library collections, including the university libraries of Utrecht and Leiden, which were referenced five and three times, and the Amsterdam municipal library, listed three times. One collection listed two Frankfurt book fair catalogues. Private library catalogues are also well represented, with two copies each of the catalogues of the library of the theologian Jacobus Trigland, auctioned in 1706, and of the prominent collector Henri-Charles, duc de Coislin, sold in 1736, as well as several dozen single copies of catalogues of the libraries of other collectors. The most frequently cited titles, however, were by Nicolaas Heinsius and Johannes Lomeier. Five of the collectors owned a copy of Heinsius' famous library auction catalogue. Another five owned copies of Lomeier's library treatise De bibliothecis. Three of them owned a more recent bibliographical reference work, Johannes van Abkoude's Naamregister van Nederduitsche Boeken (Registry of Dutch books published between 1640 and 1741), published in 1743 in Leiden. And just as interestingly, four collectors also owned a copy of one of the earliest library handbooks recorded in history, the ninth-century

71 Because of its large size - 1,823 lots, representing an even larger number of individual items - this catalogue did not meet the criteria for inclusion in the corpus of smaller catalogues used in this essay. 
Byzantine Patriarch Photius' Bibliotheca, that summarised the contents of $28 \mathrm{o}$ books. Notwithstanding this last work, however, there is a clear local bias to the choice of titles, that is in keeping with the strongly Latinate, and overwhelmingly Dutch nature of these collections, as well as the absence of non-Dutch library manuals such as Naudé's and Formey's.

Finally, these collectors' familiarity with the concept of the bibliothèque choisie is betrayed by the prominent role that Jean Le Clerc's periodicals occupy in their libraries. Seven of the 28 library auction catalogues listed one or more of Le Clerc's review journals, sometimes in complete runs. The Bibliothèque choisie was listed five times, in the library catalogues of Jacob de Goyer in 1706, in that of Frederik Rooseboom in 1717, Johannes Schulting in 1726, Joannes Cornelius de Pauw in 1750, and the pastor of the Amsterdam Walloon church, in 180o, whose library listed not only 26 volumes of the Bibliothèque choisie, but also its forerunner, the Bibliothèque universelle, and its sequel, the Bibliothèque ancienne et moderne. In addition to Le Clerc's publications, the auction catalogues list dozens of other copies and sometimes entire sets of review journals by other contemporary authors, testifying to the ubiquitous presence of the concept of the bibliothèque choisie in these libraries.

I conclude by aggregating into a new table (Table 15.10) the data discussed above on Jean Le Clerc's two review journals (abbreviated $B U H$ and $B C$ ), and his and his wife's private library auction catalogues, since both sources can be historically related to the concept of the bibliothèque choisie, as well as the corpus of 28 Dutch library auction catalogues (abbreviated 'Dutchi' and 'Dutch2' for the two halves of the century) that, because of the size of the collections recorded, might likewise be hypothesized to reflect the content of an eighteenth-century bibliothèque choisie. These different sources are now 'distant-read' by applying to them the same subject categorisation discussed

TABLE 15.10 Subject categorisation of books in review journals, auction catalogues and Formey

\begin{tabular}{lrrrrrrr} 
Category & $\boldsymbol{B}$ UH & \multicolumn{1}{c}{$\boldsymbol{B C}$} & Le Clerc & Leti & Dutch1 & Dutch2 & Formey \\
\hline Religion & $31 \%$ & $27 \%$ & $38 \%$ & $27 \%$ & $35 \%$ & $30 \%$ & $9 \%$ \\
Law & $5 \%$ & $5 \%$ & $4 \%$ & $2 \%$ & $10 \%$ & $11 \%$ & $5 \%$ \\
History & $23 \%$ & $22 \%$ & $12 \%$ & $29 \%$ & $22 \%$ & $19 \%$ & $16 \%$ \\
Arts and sciences & $21 \%$ & $13 \%$ & $16 \%$ & $7 \%$ & $8 \%$ & $10 \%$ & $24 \%$ \\
Belles-lettres & $15 \%$ & $25 \%$ & $23 \%$ & $28 \%$ & $16 \%$ & $22 \%$ & $43 \%$ \\
Uncategorised & $5 \%$ & $8 \%$ & $7 \%$ & $7 \%$ & $9 \%$ & $8 \%$ & $3 \%$ \\
\hline
\end{tabular}


above, and comparing them to the proportions obtaining in Formey's Conseils, with the last, 1764 edition serving as a point of reference.

Like other attempts to aggregate eighteenth-century book history data obtained from different sources, the resulting overview presents widely divergent ranges of proportions of books that can be assigned to each of the five conventional subject categories. ${ }^{72} \mathrm{On}$ the one hand, despite this variation between individual sources, when looked at diachronically and collectively, there does appear to be some movement toward a type of library that, in some respects, resembles the ideal incarnated by the bibliothèque choisie. The consistently strong showing, and even growth in the category 'Belles-lettres' stands out the most, with proportions ranging from $16 \%$ (Dutch1) to $27 \%$ (Leti) in libraries that can be historically associated with the emerging bibliothèque choisie. History books, too, maintain a consistently strong presence. However, the evidence on other categories, notably the catch-all 'Arts and sciences', remains less strong, given the only slight changes across the century. The conclusions are therefore mixed, and call for a number of qualifications. First of all, these overviews provide a measure not of library overlap at the level of specific titles, but at the much broader, 'distant reading' level of subject categories. Further comparative studies at the granular level of individual titles will be necessary in order to determine the exact level of similarity between auction catalogues and the prescriptions of library manuals and review journals. Secondly, there is a basic tension inherent in the very notion of the bibliothèque choisie that supposedly reflected 'private' taste, yet did so within parameters that clearly interacted with notions of a 'common' reading culture or widely-shared ideals of Bildung. Might not a library auction catalogue with a configuration of titles not approximated by any other source provide the ultimate evidence for the existence of this kind of 'personal' bibliothèque choisie, rendering all comparison by definition futile

\section{Conclusion: Will the Real Bibliothèque Choisie Please Stand Up?}

Perhaps the most plausible conclusion justified by the data comparing discursive constructions and the empirical reality of the bibliothèque choisie is that the differences in subject composition between review journals, library manuals and private library auction catalogues point to the fundamentally ideal nature of all models of libraries. Actual libraries do not ever match exactly the content of a library manual such as Formey's because eighteenth-century

72 Burrows, The French book trade, p. 92. Darnton, The literary underground, p. 18o. 
readers, like all readers, as Roger Chartier reminds us, might choose to ignore or adapt to their own needs the prescriptions of overly directive authors. ${ }^{73}$ Readers of library manuals and review journals espousing the ideals of the bibliothèque choisie probably used them, at least on occasion, as a time-saving substitute for reading the books themselves, or - similar to the use to which private library auction catalogues were sometimes put - as an aspirational book acquisition list. Like their bibliographic relative, review journals, library manuals made learning uniquely accessible: concluding his enthusiastic remarks on the Journal des savants, Jacob Bayle stressed the fact that 'those who do not have the means to spend much on books can thereby acquire a general knowledge of them without buying them' ${ }^{74}$ Conversely, libraries whose content and subject distribution displayed similarities with the ideals espoused by Le Clerc, Formey and others did not necessarily contain their works, suggesting that the concept of the bibliothèque choisie reflected more generalised cultural attitudes that were 'in the air'. Finally, the wide variability between individual collections, measured in relation to the hierarchies of knowledge proposed by intellectual gatekeepers such as Formey, also needs to be related to baser, pecuniary considerations, as well as to owners' access to print culture, and their position within the cultural field and bookscape of their day. Rather than a reflection of an enduring 'canon' or 'common culture', library manuals, review journals, and auction catalogues, with the systematisations of knowledge they represent, might most productively be conceived as the sites of an ongoing conversation on cultural values - a space for negotiation on what the bibliothèque choisie might or should be, rather than a reflection of a stable historical reality.

73 Roger Chartier, 'Communautés de lecteurs', in Culture écrite et société. L'ordre des livres (XIV ${ }^{e}-X V I I I^{e}$ siècle), (Paris: Albin Michel, 1996), pp. 133-154.

74 Correspondance de Pierre Bayle, vol. 1, p. 20. 